\title{
Extraction from DP in Italian revisited*
}

\author{
Guglielmo Cinque
}

University of Venice

\begin{abstract}
The generalization that of all arguments and
adjuncts only the subject can be extracted from a DP

in Italian (and Romance, more generally) was a

puzzle for the theory of the early '80's. It can

however be seen to follow, today, from Relativized

Minimality, the assumption that DPs are phases, and

the recognition that the escape edge of DPs is an A-,

and not an A'-, position.
\end{abstract}

Introduction. In Cinque (1980) evidence was presented that extraction from noun phrases in Italian, whether by clitic- or wh-movement, is limited to the subject. ${ }^{1}$ As acknowledged there

\footnotetext{
* I dedicate this article to Luigi, whose friendship and collaboration has accompanied me for almost forty years now. I wish to thank Giuliana Giusti, Richard Kayne, and two anonymous referees for their useful comments to a previous draft.

1 "[..] of all the NP positions of a NP, only that particular position that qualifies as the syntactic subject of the NP will be extractable” (p.80). I think the generalization still holds. Two simple diagnostics identify the subject of DP in Italian: 1) the subject is the only argument of the noun which can be expressed by a possessive adjective; 2 ) the subject is the only argument of the noun which cannot be expressed by a $1^{\text {st }}$ and $2^{\text {nd }}$ pers. sing. pronoun preceded by di. See Cinque (1980, 52ff), Giorgi (1991, §2 and §3), Rizzi (1990,chapter 3, Appendix 2), Shlonsky (1988), and the additional discussion in $\S 3$ below. Only the argument that satisfies these two conditions appears to be extractable. I return to Longobardi's (1991) interesting observation that subject clauses do not seem to fall under the generalization. The same generalization appears to hold more generally of Romance (for relevant discussion see Ruwet 1972, Milner 1977, 1982, Steriade 1981, Pollock 1989, Sportiche 1989, Valois 1991,chapter 2,§3, Kolliakou 1999 on French; Zubizarreta 1979, Torrego 1986, 1988, Demonte 1987, Campos 1988, Martín 1993, Gutiérrez-Bravo 2001 on Spanish; Díaz-Insensé 1993 on Catalan). It also seems to hold of Bulgarian (see Cinque and Krapova 2010).
} 
(p.87), this was puzzling for the theory of the time (no less than it would now for current theories), in that unexpectedly the trace of wh-movement would seem to be subject, within DPs, to a condition, the Specified Subject Condition (or Principle A of the Binding Theory), which only holds of anaphors, including the trace of A-movement and that of cliticmovement. $^{2}$

In the present article, some 30 years later, I return to this puzzle as I believe more recent findings may suggest a principled solution.

The proposed solution rests on the following four tenets: ${ }^{3}$

(1) DPs are phases (which forces movement to the highest specifier of DP, before extraction takes place).

It is sometimes claimed that "the thematic hierarchy (Possessor $>$ Agent $>$ Theme) regulates extraction out of DP" (Moritz and Valois 1994,681ff; also see Kolliakou 1999,714; Alexiadou, Haegeman and Stavrou 2007, 583ff; and Ticio 2010, chapter 2), in that Themes can be extracted if no Agent/Experiencer nor Possessor is present and Agents/Experiencers can be extracted if no Possessor is present. But this is true only in as much as thematic roles enter into the determination of what eventually counts as the syntactic subject. When divorced from the notion of subject the thematic hierarchy fails to predict what can be extracted and what cannot. Not all Agents/Experiencers can extract in the absence of Possessors (e.g. those introduced by a by phrase). Not all Themes can extract in the absence of Agents/Experiencers and Possessors (for example the Theme of Ns like desiderio 'desire', etc. - cf. Cinque 1980,64, Longobardi 1991,66, and Kolliakou 1999, §2.3). Ultimately, only what qualifies by the two diagnostics above as the syntactic subject of the DP can extract.

Ticio (2010, §2.3.2.2) claims that in Spanish certain adjunct PPs can extract from DP on a par with argument PPs, but the conclusion appears to be based on a dubious interpretation of the data. Also some of the putative counterexamples from French presented in Godard (1992) and Kupferman (1996) seem to me not to be cogent, though some need to be looked into more carefully.

${ }^{2}$ The puzzle of the apparent anaphoric status of wh-traces within DPs is further compounded by the fact that subsequent movement outside of the DP is instead unbounded:

(i) $\quad \operatorname{Di~chi}_{\mathrm{i}} \ldots$ [speravi [che si decidessero [a ripubblicare [ $\mathrm{t}_{\mathrm{i}}$ le opere]]] ?

Of whom ... were you hoping that they would decide to republish the works

${ }^{3}$ This proposal has some points in common with that of Gutiérrez-Bravo (2001), at least in taking DPs to be phases and in invoking a locality condition. 
(2) The highest specifier of DP in Italian (the one through which extraction takes place) is an A- (rather than an A'-) position, as the evidence seems to suggest.

(3) The specifier hosting the subject of DP is not the highest specifier of DP.

(4) Movement is subject to locality conditions; specifically, I will assume, to Rizzi’s (1990, 2001, 2004) Relativized Minimality.

From these tenets it follows that in Italian any extraction from DP other than the subject's will cause a violation of Relativized Minimality, due to the intervention of the subject of DP (also an A-position), thus yielding an account of the original generalization. ${ }^{4}$

I take up the four tenets in turn. ${ }^{5}$

1. The phasehood of DPs. Since the introduction in Chomsky (2000, 2001) of the notion of Phase and of the concomitant Phase Impenetrability Condition, which allow only the highest head and the phrase in its specifier to extract from a phase, the question arises of which syntactic constituents qualify as phases. If DPs, in addition to vPs and CPs, are phases (see Chomsky 2008,143, and references cited there; as well as Gutiérrez-Bravo 2001, den Dikken 2006, and Biberauer, Holmberg and Roberts 2010, sect.5.1.1), it follows that only those elements which can raise to the highest specifier of DP will be able to extract from it. This has the advantage of subsuming the accounts of extraction from DP based on Subjacency (Stowell

\footnotetext{
${ }^{4}$ From the highest Spec,DP, movement then procedes as an ordinary (A to) A'-movement (much like who moves, in (i), to an A'-position from a derived A-position, thus accounting for the unbounded nature of the movement noted in fn.2):

(i) $\quad \mathrm{Who}_{\mathrm{i}}$ [do you think [ $\mathrm{t}_{\mathrm{i}}$ they said [ $\mathrm{t}_{\mathrm{i}}$ [ $\mathrm{t}_{\mathrm{i}}$ seemed [ to be the culprit]]]]]?

${ }^{5}$ It remains to be seen how this analysis can be made compatible with Kayne's (2008) analysis of Ns according to which Ns can neither have complements nor specifiers (also see fn. 22 below).
} 
1987, Campos 1988) as well as those based on Proper Government (Longobardi 1991, Rizzi

1990, Chapter 3, Appendix 2), while avoiding the problems that those accounts raise. Quite apart from the observation that (Antecedent) Government has no place in current theory, the fact that the subject of DP does not occupy the highest specifier of DP (see §3 below) weakens a pure government-based account of extraction. The reason is that it is no longer clear why adjuncts and arguments other than the subject could not use Spec,DP as an escape hatch, if that were an A'-position distinct from the subject's A-position.

2. The edge of DP as an A-position in Italian. Although a number of authors have claimed, or assumed, that Spec,DP is an A'-position ${ }^{6}$, there is evidence that at least in Italian it is not. For one thing, as noted in Giusti (1996, 107), no wh-phrase can check its interrogative feature in Spec,DP. Consider the subcategorization possibilities of a verb like scoprire 'discover, find out' in Italian. It selects either an interrogative sentential complement ((5)a), or a DP complement ((5)b) (as well as a declarative sentential complement: Ho scoperto che è un imbroglione 'I discovered that he is a crook'):

(5) a. Hai scoperto [cP perché l’ha fatto] ?

Have you discovered why he did it?

b. Hanno scoperto [Dp il nostro interesse per Maria]

They discovered our interest in Maria

\footnotetext{
${ }^{6}$ See, among others, Aoun (1985, §2.6), Horrocks and Stavrou $(1987,103)$, Mouma (1993, 1994), Díaz-Insensé (1993), Aissen (1996) (and Gavruseva 2000 relatively to Hungarian, Chamorro and Tzotzil), although no decisive evidence is given there except that it is the position through which extraction from DP takes place. Sportiche $(1989,40 \mathrm{f})$ assumes instead that Spec,NP, and Spec, $\mathrm{N}^{\mathrm{MAX}}$ are A-positions. Haegeman $(2004,214)$ also argues that movement of the possessor to Spec,DP is an instance of A-movement in West Flemish, and Germanic, more generally (a conclusion shared by Gavruseva 2000, §5). Szabolcsi (1994) does not take a definite stand on the A- or A'-status of the highest Spec of DP in Hungarian (the one hosting a dative possessor). See her discussion on p.203, and also §2.1 below.
} 
As Giusti (1996) observes, if DPs in Italian were like CPs in having a left periphery containing an interrogative A'-specifier which could host a wh-phrase, then we might expect such verbs, which take a DP object and s-select an interrogative complement, to allow for a fronted wh-phrase within DP, as in (6); but that is not possible: ${ }^{7}$

(6) *Hanno scoperto [DP [per chi $]_{\mathrm{i}}$ il nostro interesse $t_{\mathrm{i}}$ ]

They.have discovered in whom our interest

Similarly, no focus nor topic phrase can raise to the front of a DP. See (7)a and b, respectively:

(7) a. *[Ci ha sorpreso [[PER MARIA] (non per Ada) il suo interesse]

Us surprised for M. (focus) (not for A.) his interest

b. *[[Per Maria] il suo interesse personale (non quello professionale)] ha sorpreso tutti for M. his personal interest (not the professional one) surprised everybody

A second piece of evidence that the highest Spec of DP is an A-, rather than an A'-, position in Italian may come from the syntax of the reciprocal construction. As shown in Belletti (1982/83), the reciprocal discontinuous anaphor l'un...l'altro in Italian is subject to a double binding requirement.

\footnotetext{
${ }^{7}$ Even in (marginal) sluicing cases like (i) (where the whole DP is presumably moved to the Spec,CP of a silent IP) fronting of the wh-phrase is impossible (cf. (i)b):

(i) a. [Hanno arrestato il figlio di qualche importante uomo politico 'They arrested the son of some important politician']

?Avete scoperto [il figlio di chi]?

have you discovered the son of whom?

'Have you discovered whose son they arrested?

. b *Avete scoperto [di chi il figlio]?

have.you discovered of whom the son?
} 
It, as a discontinuous whole, must find a local antecedent in A position to satisfy Binding principle A (cf. (8)a-c); the second part of the discontinuous whole, l'altro, which occupies the thematic A-position, must also be locally bound by the first part, l'uno. See the contrast between (9) and (10), where a subject, the possessive adjective tue 'your', intervenes between the two: ${ }^{8}$

(8) a. I miei amici hanno parlato [l'uno [dell'altro]] (Belletti 1982/83,113)

My friends have spoken one about the other

b. *Mario ha parlato [l'uno [dell'altro]] (Belletti 1982/83,113)

Mario has spoken one about the other

c. *I miei amici sostennero che Mario parlò [l'uno [dell'altro]] (Belletti 1982/83,113)

My friends claimed that Mario spoke one about the other

(9) Quei reporters ammiravano [l'uno [le foto dell'altro]] (Belletti 1982/83,107)

Those reporters admired one the pictures of the other

(10) *Quei reporters ammiravano [l'uno [le tue foto dell'altro]] (Belletti 1982/83,107)

Those reporters admired one your pictures of the other

All of this suggests that l'uno at the left edge of the DP is also in an A-position, a conclusion supported by another observation of Belletti's. On the basis of the paradigm in (11), she notes that l'uno can function as a 'configurational (if not a thematic) subject'. In her own words: "In (11)a the adjective vicin-, which is outside of the reciprocal construction, agrees in gender and number with the feminine plural subject NP le mie amiche; in (11)b, where l'una is in the

\footnotetext{
${ }^{8}$ Though some speakers find (10) not to be completely ungrammatical.
} 
adjoined position inside the AP whose head is the adjective vicin-, the adjective agrees with l'una and is thus feminine singular. As (11)c shows, when l'una is inside the AP, the adjective not simply can, but rather must agree with it. The situation in (11) may then appear rather paradoxical: an adjective does not agree with the subject of the clause in (11)b; and it cannot do so as the star in (11)c shows. However, if we assume that a different subject is present in (11)b,c, namely the configurational subject of the AP l'una, the agreement in (11)b follows directly: it is a standard case of subject/adjective agreement. The impossibility of the agreement in (11)c follows as well, from the same assumption.” (p.106). ${ }^{9}$

(11) a. Le mie amiche rimasero vicine [pp l'una [pp all'altra]]

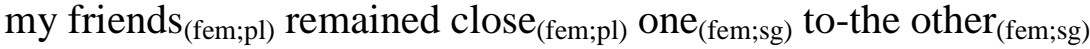

b. Le mie amiche rimasero [AP l’una [AP vicina all'altra]] my friends (fem;pl) $_{\text {remained one }}$ (fem;sg) close $_{(\mathrm{fem} ; \mathrm{sg})}$ to-the other $(\mathrm{fem} ; \mathrm{sg})$

c. * Le mie amiche rimasero [AP l'una [AP vicine all'altra]]

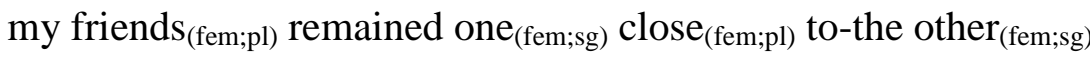

The fact that exactly the same paradigm is found with (predicate) DPs (see (12) below) suggests that the left edge of DP, where l'uno occurs, can also function as a configurational (if not a thematic) subject of DP.

(12) a. I miei amici sono sempre stati [i peggiori sostenitori [pp l'uno [pp dell'altro]]]

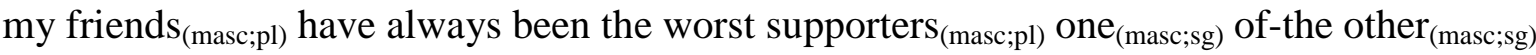
b. I miei amici sono sempre stati [l’uno [il peggior sostenitore [pp dell’altro]]]

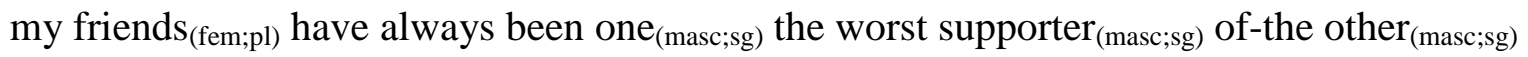

\footnotetext{
${ }^{9}$ Also see her endnote 6.
} 
c. *I miei amici sono sempre stati [l’uno [i peggiori sostenitori [pP dell'altro]]]

my friends (masc;pl) have always been one (masc;sg) $_{\text {twe }}$ the worst supporters $_{(\text {masc;pl) }}$ of-the other (masc;sg)

The position occupied by l'uno appears to be the highest Spec of DP, above the article, in fact above the projection hosting universal quantifiers, which is itself above the projection(s) hosting the demonstrative and the article (cf. (13)): ${ }^{10}$

(13) Quei reporters ammiravano [l’uno [quasi tutte [queste/le [foto dell'altro]]]]

'Those reporters admired one almost all these/the pictures of the other'

I will thus conclude that the highest specifier position of the extended projection of the NP in Italian is an A-position. ${ }^{11}$

2.1 Other languages in which the edge of DP may be an A-position. In addition to Italian (and presumably Romance, in general), there appear to be other languages in which the edge of DP is arguably an A-position. I mentioned in fn.6 Gavruseva’s (2000) and Haegeman’s (2004) conclusion that raising of the possessor to Spec,DP in Germanic is an instance of Amovement. Hungarian is possibly another case in point. Although Szabolcsi (1994) does not take a definite stand on the A or A' status of the highest specifier of DP in Hungarian, she observes that that position is one of (Dative) Case assignment (a property typically associated

\footnotetext{
${ }^{10}$ This may actually suggest that DP as the maximal extended projection of NP is a misnomer (except for the fact that $\mathrm{D}$ is the highest overt head of the nominal extended projection, higher elements plausibly being phrases in specifier positions).

${ }^{11}$ This may not be compatible with Chomsky's $(2008,15)$ derivational definition of A- and A'-positions, according to which the edge of a phase head is an A'-bar position, all other positions being A-positions.
} 
with A-positions) ${ }^{12}$, and, more importantly, that only possessors, and subjects of complex event nominals can be found there (Anna Szabolcsi, personal communication), which could be made to follow from Relativized Minimality if that is an A-position (as we argue below to be the case for the same facts in Bulgarian).

As just mentioned, Bulgarian is another language where the edge of DP appears to have properties of an A-position. ${ }^{13}$ This language allows fronting of a constituent to the absolute initial position of the DP, as can be seen from the fact that in (14) the na-phrase precedes all strong determiners (the universal quantifier and the demonstrative, as well as other alternative possible occupants of Spec,DP - cf. Dimitrova-Vulchanova and Giusti 1999,§4).

(14) $\mathrm{Na}$ Ivan vsički tezi opisanija na prijatelite mu of Ivan all these descriptions of friends-the his 'All of these descriptions of his friends by Ivan'

Evidence that this position is an A-position comes from the fact that of all adjuncts and arguments of the DP (adjunct PPs, (15a), subcategorized PPs (15b), dative na-phrases (15c), object na-phrases (15d) and subject na-phrases (15e)), only that argument which qualifies as the subject can move to that position ((15e)):

\footnotetext{
12 Though some cases appear to exist of Exceptional Case Marking into an A'-position (Spec of CP). See Kayne's (1980,§1.3) discussion of such cases as (i) (in some varieties of English):

(i) the man whom I believe has left...

Perhaps, in the man who I believe has left, who is assigned both nominative (in Spec IP) and Accusative (in Spec CP), which might in turn be at the basis of the contrast pointed out to me by Richard Kayne (p.c.) between You, I don't think will be chosen and *Me/*I you don't think will be chosen (do you?), which recalls the contrast between (ii)a. and b. in Norwegian topicalization noted by Taraldsen (1981,378f) (and which should be possible in the varieties of English that accept (i), perhaps contrary to fact):

(ii)a. ${ }^{*} \mathrm{Jeg} / *^{*} \mathrm{du} / *^{*}$ vi hadde de trodd ville komme forsent

$\mathrm{I} /$ you(sg)/we had they thought would arrive too late

b. Han/dere hadde de trod ville komme forsent he/you(pl) had they thought would arrive too late

13 This section is based on §3.1 of Cinque and Krapova (2010).
} 
(15) a. *Direktorăt razkritikuva [[văv vestnika $]_{\mathrm{i}}$ statijata na žurnalista $\left.\mathrm{t}_{\mathrm{i}}\right]$ director-the criticized-3sg [[in newspaper-the] article-the of journalist-the]

b. *Žurnalistăt razkritikuva [[za tazi kniga $]_{\mathrm{i}}$ obštoprietoto mnenie $\left.\mathrm{t}_{\mathrm{i}}\right]$ journalist-the criticized-3sg [[for this book] common-the opinion]

c. ${ }^{*}$ Učitelite razkritikuvaxa [[na detsata $]_{\mathrm{i}}$ razdavaneto na knigi $\mathrm{t}_{\mathrm{i}}$ (ot sponsorite)] teachers-the criticized-3pl [[to children-the] distribution-the of books (by sponsors-the)]

d. *Direktorăt na spisanieto razkritikuva $\left[[\text { na săbitieto }]_{i}\right.$ negovoto opisanie $\left.t_{i}\right]$ director-the of journal-the criticized-3sg [[of event-the] his description]

e. Az razkritikuvax [[na Ivan $]_{\mathrm{i}} \mathrm{t}_{\mathrm{i}}$ mnenieto na kăštata $]$ I criticized-1sg of Ivan opinion-the of house-the 'I criticized Ivan's opinion of the house'

This curious restriction can again be understood as a consequence of Relativized Minimality if the edge of DP is an A-position (see §4 below). If it were an A'-position, we would expect any argument or adjunct to be able to move into it, much like topic-, focused- and wh-phrases can front in Bulgarian to the left periphery of the clause (Krapova 2002):

(16) a. Po tozi văpros Ivan ništo ne kaza.

for this matter Ivan nothing not said-3sg

'On this matter, John said nothing'

b. VĂV VESTNIKA pročetox tazi statija.

in newspaper-the (focus) read-1sg this article

'It was in the newspaper that I read this article'

c. Ivan kakvo misli po văprosa? 
Ivan what thinks on question-the

'Ivan, what does he think of this issue?'

Whether the edge of DP can be an A'-position (or a sequence of A'-positions) in other languages remains to be determined. ${ }^{14}$ Extraction from DP in English (if real) appears to obey quite different conditions from Italian/Romance, or Bulgarian. ${ }^{15}$ See for discussion ErteshikShir (1981), Pollock (1989), Davies and Dubinsky (2003), and references cited there.

3. The position(s) of the subject. The highest of the positions which the subject can occupy in the Italian DP appears to be below the universal quantifier tutto 'all', the demonstratives and the determiners, and (preferably) below such high functional adjectives as stesso 'same' and altro 'other' (Kayne 2005,13). See (17): ${ }^{16}$

(17) a. [ quasi tutti [ questi/gli [stessi/altri [suoi[ dieci[accorati [appelli al presidente]]]]]]]

\footnotetext{
${ }^{14}$ Modern Greek appears to allow the fronting of topic-, focused-, and wh-phrases between the Demonstrative and the Determiner (see Nthelithos 2002), but of all arguments only subjects can extract, suggesting the presence of a lower A-position above the Merge position of the subject, to which arguments raise before raising to the topic/focus/wh-field.

15 As shown by Ross’s (1967, § 4.3.1) celebrated example (i), a DP can (apparently) be extracted from the most deeply embedded of a series of DPs, but one cannot be absolutely sure that real extraction is involved (rather than A'-binding of a silent resumptive pronominal), especially given the contrast that Ross himself observes between apparent DP extraction (possible) and PP extraction from the same environments (impossible). See the contrast between (i) and (ii), and that between (iii)a and b:

(i) The reports which the government prescribes the height of the lettering on the covers of... (Ross 1967,197)

(ii) *The reports of which the government prescribes the height of the lettering on the covers... (Ross 1967,201)

(ii) a. Which Greek authors does he have books by? (Ross 1967,201)

b. ?*By which Greek authors does he have books? (Ross 1967,201)

16 The possessive adjective can also appear in lower positions: after the numeral, after the adjective, in between the noun and the PP complement, and at the very end of the DP, this last position requiring particularly heavy stress. I set the question of the status of these positions to the side here.
} 
almost all these/the same/other his ten heartfelt appeals to the President

'almost all these/the same/other ten heartfelt appeals of his to the President'

b. ?[quasi tutti [ questi/i [suoi [stessi/altri [ dieci[accorati [appelli al presidente]]]]]]

almost all these/the his same/other ten heartfelt appeals to the President

c. *[quasi tutti [suoi [ questi/gli [stessi/altri [ dieci[accorati [appelli al presidente]]]]]]]

almost all his these/the same/other ten heartfelt appeals to the President

$\mathrm{d} *[$ suoi [quasi tutti [ questi/gli [stessi/altri [ dieci[accorati [appelli al presidente]]]]]]

his almost all these/the same/other ten heartfelt appeals to the President

Quite clearly, then, the highest of the positions which the subject can occupy is not the highest specifier of the extended nominal projection. The fact that differently from the subject introduced by di 'of', to which we return, possessive adjectives cannot be extracted (see (18) vs. (19)) might be attributed to their occupying the criterial subject position of the DP (in the sense of Rizzi 2007 and Rizzi and Shlonsky 2007); whence their being frozen in place. ${ }^{17}$

(18) a. Abbiamo visto [la sua borsa]

We.have seen the his bag

b. ${ }^{*} \mathrm{SUA}_{\mathrm{i}}$ abbiamo visto [la $\mathrm{t}_{\mathrm{i}}$ borsa]

His (focus) we.have seen the bag

${ }^{17}$ For a different account see Longobardi $(1991, \S 10)$. If the nominative subject of the Hungarian DP is the criterial subject position, then the non-extractability of the nominative subject (as opposed to the dative subject at the edge of DP) could also be taken to follow from Rizzi's (2007) Criterial Freezing. The same might hold of English and Germanic pronominal genitive subjects (whose, wessen, etc.). Cf. Gavruseva (2000,§5). Their frozen character may also follow from Chomsky's $(2008,16)$ Generalized Inactivity Condition.

Note that possessive adjectives unproblematically move under focus movement from other positions (such as the predicative one):

(i) $\mathrm{SUA}_{\mathrm{i}}$ credo che fosse $\mathrm{t}_{\mathrm{i}}$ (, la borsa)

His (foc.) I.think that was (, the bag) 
(19) a. Abbiamo visto [la borsa di Gianni]

We.have seen the bag of Gianni

b. DI GIANNI $\mathrm{i}_{\mathrm{i}}$ abbiamo visto [la borsa $\mathrm{t}_{\mathrm{i}}$ ]?

Of Gianni (focus) we.have seen the bag

As for the subject and object DP preceded by the preposition di 'of', I will assume movement from their thematic (Merge) position to a licensing position (Spec $\operatorname{Agr}_{\mathrm{S}} \mathrm{P}$ or NominativeP and Spec of $\operatorname{Agr}_{0} \mathrm{P}$ or AccusativeP, respectively). Subject and object DPs further move to the Specifier of a genitive Case projection, licensed by the subsequent insertion of the preposition $d i$, which attracts the remnant to a higher specifier, as in Kayne's (1999, 2000, 2001, 2004) analysis of (functional) prepositional phrases: ${ }^{18}$

(20) a. [XP Gianni [NP opinione ]] merger of $\mathrm{Agr}_{\mathrm{s}}$ and attraction of Gianni to its Spec $\rightarrow$

b. [AgrP Gianni ${ }_{\mathrm{k}} \operatorname{Agr}_{\mathrm{s}}\left[\mathrm{XP} \mathrm{t}_{\mathrm{k}}[\mathrm{NP}\right.$ opinione $\left.\left.]\right]\right]$ merger of $d i$ and attraction of the remnant $\rightarrow$

c. [[XP $t_{\mathrm{i}}\left[\mathrm{NP}\right.$ opinione ]] [G di [aGP Gianni $\mathrm{k}_{\mathrm{k}}$ Agr [XP ]]] merger of the criterial position of subject (expletive pro if $\mathrm{Agr}$ is $\mathrm{Agr}_{\mathrm{s}}$ ) $\rightarrow$

d. [Subjp $\operatorname{pro}_{\mathrm{k}}$ Subj [[xp $\mathrm{t}_{\mathrm{i}}$ [NP opinione ]] [G di [AGP Gianni $\mathrm{k}_{\mathrm{k}}$ Agr [xP ]]] merger of Det $\rightarrow$

e. [DP l' [SubjP pro $_{\mathrm{k}}$ Subj [[XP t $_{\mathrm{i}}\left[\mathrm{NP}\right.$ opinione ]] [G di [AGP Gianni ${ }_{\mathrm{k}}$ Agr [XP ]]]

While the clausal preposition di 'of', prevents its 'complement' DP from c-commanding out of the maximal projection that contains them (*Parlò male del re ${ }_{k}$ ai propri ${ }_{k}$ consiglieri 'He said vicious things about (lit. of) the king to his advisors', *Si è vantata del figlio ${ }_{k}$ con $i$ propri $_{k}$ compagni 'She boasted about (lit. of) her son with his friends'), the adnominal di 'of',

\footnotetext{
${ }^{18}$ As suggested in the next section, lack of person agreement in the Italian DP requires the subject and object DPs to receive an additional Case (genitive), licensed by di; which is one way to render Benveniste's $(1966,146 f)$ idea that genitive is what translates, within the (Latin) $\mathrm{DP}$, clausal nominative and accusative (what he calls the génitif de transposition).
} 
as noted in Giorgi $(1991, \S 2)$, does not (l'appello del re $e_{k}$ ai propri $i_{k}$ sudditi 'the appeal of the king to his subjects', la lotta del re $e_{k}$ contro i propri ${ }_{k}$ oppositori 'the fight of the king against his opposers'). This could be taken to suggest that the di introducing the latter is a prepositional head belonging to the extended projection of the genitive Case head rather than the head of an independent prepositional projection (Giorgi 1991 assumes it to be "a semantically empty realization of the Genitive Case” (p.29)).

The ungrammaticality (or marginal status) of two di-phrases with derived nominals based on transitive verbs (*[la distruzione [del ponte] [dei nemici]] 'the destruction of the bridge of the enemies'/[*la distruzione [dei nemici] [del ponte]] 'the destruction of the enemies of the bridge', as opposed to [la distruzione [del ponte] [da parte dei nemici]] 'the destruction of the bridge by the enemies' and [la [loro] distruzione [del ponte]] 'their destruction of the bridge' may suggest that, in the Italian DP, only one di is available to license genitive Case (which may instead combine with the genitive plausibly realized by the possessive adjective). Where two di appear to be (marginally) possible ([l'organizzazione [della mostra] [di Gianni]] 'the organization of the exhibition of G.', the subject di Gianni might in fact be a reduced relative clause ([l'organizzazione [della mostra] [(che era) di Gianni]] 'the organization of the exhibition which was by Gianni'. Evidence for this conclusion appears to come from the contrast between (21)a and b (which contain the discontinuous anaphor l'un l'altro 'one another'):

(21) a. *La presentazione [degli ospiti] [gli uni degli altri]/[gli uni degli altri] [degli ospiti] The introduction of the guests of one another/of one another of the guests

b. La presentazione [degli ospiti] [gli uni agli altri]/[gli uni agli altri] [degli ospiti]

The introduction of the guests to one another/to one another of the guests 
The anaphor, which is possible when introduced in a dative argument, is completely impossible in a second $d i$ phrase, just as it is in the predicate of a relative clause $(* l a$ presentazione degli ospiti che era stata fatta gli uni agli altri 'the introduction of the guests which had been done one to the other').

Also see the discussion below on DP-internal pronominals introduced by $d i$.

3.1 The restriction on $1^{\text {st }}$ and $2^{\text {nd }}$ pers. sing. pronouns as subjects. If we take $\operatorname{Agr}_{\mathrm{o}}$ and $\mathrm{Agr}_{\mathrm{s}}$ to assign accusative and nominative Case in the DP just as they do in finite clauses (except that in Italian DPs the lack of (subject and object) agreement requires the insertion of an additional Case marker assigning genitive on top of the already assigned accusative and nominative ${ }^{19}$ ), perhaps we can make sense of the curious prohibition against $1^{\text {st }}$ and $2^{\text {nd }}$ pers. sing. pronouns as subjects noted in Cinque (1980,52ff). ${ }^{20}$

These are the only tonic pronouns of Italian which have a morphologically distinct form for nominative and non-nominative (accusative and the oblique Cases assigned by different prepositions): io ( $1^{\text {st }}$ pers. sing. nominative), me ( $1^{\text {st }}$ pers. sing. non-nominative), tu $\left(2^{\text {nd }}\right.$ pers. sing. nominative), te ( $2^{\text {nd }}$ pers. sing. non-nominative).$^{21}$

${ }^{19}$ This is one way to render Benveniste's $(1966,146 f)$ idea that genitive is what translates, within the (Latin) DP, clausal nominative and accusative (what he calls the génitif de transposition).

${ }^{20}$ This restriction is lifted under coordination (Belletti 1978). Neither the filter discussed in Cinque (1980) nor the principle suggested in Giorgi (1991,37) are actually able to discriminate between $1^{\text {st }}$ and $2^{\text {nd }}$ person singular pronouns on one side and all other pronouns on the other. Giorgi's (pragmatic) principle is however needed (in addition to what I propose here for the impossibility of $1^{\text {st }}$ and $2^{\text {nd }}$ person singular pronouns as subjects) to account for the preference of a $1^{\text {st }}$ and $2^{\text {nd }}$ person plural and $3^{\text {rd }}$ person singular and plural possessive adjective over the corresponding pronouns in the absence of contrast (much like the principle which renders in Italian finite clauses a null pronominal subject preferable, in the absence of contrast, to an overt one).

${ }^{21} 1^{\text {st }}$ and $2^{\text {nd }}$ person plural, and $3^{\text {rd }}$ person singular and plural tonic pronouns (noi, voi, lui, lei, loro) instead have only one morphological form. I ignore egli, a weak nominative $3^{\text {rd }}$ pers. masc. sing. pronoun belonging to archaic and literary Italian (Cardinaletti 1997,§2.2; 2004,§4.2).

$T e$ in (sloppy) colloquial Italian has certain apparent usages as a subject: 
All this means that for those pronouns which are morphologically underspecified for the nominative/non-nominative distinction no problem will arise in subject position (where both nominative and genitive (non-nominative) are assigned). A problem will instead arise with those pronouns (notably $1^{\text {st }}$ and $2^{\text {nd }}$ person singular pronouns) which have two distinct morphological forms. For the morphologically nominative form will be compatible with the nominative assigned by $\operatorname{Agr}_{\mathrm{s}}$ but not with the genitive Case, and the morphologically nonnominative form will be compatible with the genitive but not with the nominative Case. In other words, with $1^{\text {st }}$ and $2^{\text {nd }}$ person singular pronouns there is no morphological form which is compatible with the Cases assigned to the DP subject; whence the noted restriction. ${ }^{22}$

\section{Relativized Minimality.}

The last tenet that the present account of extraction from DP in Italian rests on is Locality; namely the impossibility for A-movement to Spec,DP to cross over the intervening A-position occupied by the subject. I will take this to follow straightforwardly from Rizzi's (1990) formulation of Relativized Minimality (and subsequent refinements; see Rizzi 2001, 2004; and also Krapova and Cinque 2008,§7, based on Chomsky 2001 and unpublished work by Rizzi).

(i) a. Vacci te!

go there you

'YOU go!'

b. (?)Te non mi piaci

you not to.me appeal

'I don't like you'

However, the impossibility of using it in the only non-pro-drop subject position of Italian $\left(2^{\text {nd }}\right.$ pers. sing. of the present subjunctive: Penso che $t u /{ }^{*} 0 / *$ te sia matto 'I think that you are (lit. be) crazy'), casts doubt on te being a nominative form. The only 'subject' positions where it can appear are the inverted subject position of (i)a, and what is possibly a (CL)LD one ((i)b). What Case these positions may receive (in alternative to the nominative) is left open here.

${ }^{22}$ This recalls the English and Norwegian Topicalization cases mentioned in fn.12 above and the morphological Case matching requirement in German free relatives discussed in Groos and Riemsdijk (1981). 


\section{Conclusion.}

In sum, the fact that in Italian (and other languages) extraction from DP is limited to the subject follows, if we are right, from the interaction of certain principles of UG (the notion of phase and Relativized Minimality) and certain independently justifiable properties of the language(s) in question, in particular, the A-status of the highest specifier of DP. ${ }^{23}$

The raising to Spec,DP (an A-position) of any adjunct or argument other than the DP subject will cause a violation of Relativized Minimality due to the intervention of the subject of DP, also an A-position. ${ }^{24}$

\section{References}

Aissen, Judith. 1996. Pied-piping, abstract agreement, and functional projections in Tzotzil. Natural Language and Linguistic Theory 14, 447-491.

${ }^{23}$ Longobardi $(1991, \S 4)$ observes that clauses resist extraction from DP even when they are the only argument of the head $\mathrm{N}$, hence plausibly (in a chain with) its subject:

(i) *Una guerra, [che ci sia la quale $]_{i}$ io non so valutare [la probabilità $\left.t_{i}\right]_{\text {,.. }}$

A war, that there will be which I cannot evaluate the probability,.. (cf. Longobardi, 1991,72)

(cf. Un evento di cui non so valutare la probabilità.. 'an event of which I cannot evaluate the probability')

He attributes this failure to the more general impossibility for clauses to occur in subject position (cf. *[That Mary will come $]_{\mathrm{i}}$ 's probability $\mathrm{t}_{\mathrm{i}}(=\mathrm{his}(39 \mathrm{~b})$ ). Under the present analysis, one would also have to account for why a clause cannot access the highest specifier of DP before extraction. An answer may come from one part of Kayne's (2008, to appear) analysis of Ns (assuming it can be made compatible with our analysis of extraction from DP, as noted above). According to this part of Kayne's analysis, the apparent clausal argument of a $\mathrm{N}$ is in fact a hidden relative clause. If so, it is to be expected that it may not extract, just like relative clauses cannot extract out of the DP which contains them (*[That we met yesterday $]_{\mathrm{i}} I$ don't want to see the man $\mathrm{t}_{\mathrm{i}}$ ).

${ }^{24}$ For additional, orthogonal, factors constraining extraction from DP (perhaps universally), such as Specificity and Proper Government (which would now need to be reconsidered in minimalist terms), see Fiengo and Higginbotham (1981) and Longobardi (1991), respectively. 
Alexiadou, Artemis, Liliane Haegeman and Melita Stavrou. 2007. Noun Phrase in the Generative Perspective. Berlin: Mouton de Gruyter.

Aoun, Joseph. 1985. A Grammar of Anaphora. Cambridge, MA: MIT Press.

Belletti, Adriana. 1978. Strutture coordinate e possessivi. Rivista di grammatica generativa 3:127-142 http://lear.unive.it/bitstream/10278/2198/1/3_belletti.pdf

Belletti, Adriana. 1982/83. On the Anaphoric Status of the Reciprocal Construction in Italian. The Linguistic Review 2:101-137

Benveniste, Émile. 1966. Pour l'analyse des fonctions casuelles: le génitif latin. In É.Benveniste Problèmes de linguistique générale. 140-148. Paris: Gallimard.

Biberauer, Theresa, Anders Holmberg and Ian Roberts. 2010. A syntactic universal and its consequences. Ms. University of Cambridge and Newcastle University.

Campos, Héctor. 1988. Extraction from NP in Spanish. Romance Linguistics and Literature Review 1:1-32

Cardinaletti,Anna. 1997. Subjects and Clause Structure. In L.Haegeman, ed., The New Comparative Syntax. 33-63. London: Longman.

Cardinaletti, Anna. 2004. Toward a Cartography of Subject Positions. In L.Rizzi, ed., The Structure of CP and IP. The Cartography of Syntactic Structures, volume 2. 115-165. Oxford: Oxford University Press.

Chomsky, Noam. 2000. Minimalist Inquiries: the framework. In R.Martin, D.Michaels, J.Uriagereka, eds., Step by Step: Essays on minimalist syntax in honor of Howard Lasnik. 89155. Cambridge, Mass.: MIT Press.

Chomsky, Noam. 2001. Derivation by Phase. In M.Kenstowicz, ed., Ken Hale: A life in language. 1-52. Cambridge, Mass.: MIT Press. 
Chomsky, Noam. 2008. On Phases. In R.Freidin, C.Otero, and M.-L. Zubizarreta, eds., Foundational Issues in Linguistic Theory. Essays in Honor of Jean-Roger Vergnaud. 133166. Cambridge, MA: MIT Press.

Cinque, Guglielmo. 1980. On Extraction from NP in Italian. Journal of Italian Linguistics. 5:47-99 (also in G.Cinque. 1995. Italian Syntax and Universal Grammar. 7-53. Cambridge: Cambridge University Press).

Cinque, Guglielmo and Iliyana Krapova. 2010. The case for genitive Case in Bulgarian. To appear in L.Schürcks, A.Giannakidou, U.Etxeberria and P.Kosta, eds., Nominal Constructions in Slavic and Beyond. Berlin: Mouton de Gruyter.

Davies, William D. and Stanley Dubinsky. 2003. On Extraction from NPs. Natural Language and Linguistic Theory 21:1-37

Demonte, Violeta. 1987. Rección y minimalidad en el sintagma nominal. In V. Demonte and M. Fernández Lagunilla, eds., Sintaxis de las lenguas románicas. 252-290. Madrid: El Arquero.

Den Dikken, Marcel. 2006. Phase Extension. Contours of a Theory of the Role of Head Movement in Phrasal Extraction.

http://web.gc.cuny.edu/dept/lingu/dendikken/docs/phase_extension.pdf

Díaz-Insensé, Natàlia. 1993. Catalan Possessives: Extraction from DP and Strong Crossover. In M.Mazzola, ed., Issues and theory in Romance linguistics. 285-302. Washington (D.C.): Georgetown University Press.

Dimitrova-Vulchanova, Mila and Giuliana Giusti. 1999. Possessors in the Bulgarian DP. In M.Dimitrova-Vulchanova and L.Hellan, eds., Topics in South Slavic Syntax and Semantics. 163-192. Amsterdam: Benjamins. 
Erteschik-Shir, Nomi. 1981. On Extraction from Noun Phrases (Picture Noun Phrases). In A.Belletti, L.Brandi, and L.Rizzi, eds., Theory of Markedness in Generative Grammar. Proceedings of the 1979 GLOW Conference. 147-169. Pisa: Scuola Normale Superiore.

Fiengo, Robert and James Higginbotham. 1981. Opacity in NP. Linguistic Analysis 7:347-373

Gavruseva, Elena. 2000. On the syntax of possessor extraction. Lingua 110:743-772

Giorgi, Alessandra. 1991. On NPs, $\theta$-marking and c-command. In A.Giorgi and G.Longobardi The syntax of Noun Phrases. Configuration, parameters and empty categories. 22-56. Cambridge: Cambridge University Press.

Giusti, Giuliana. 1996. Is there a FocusP and a TopicP in the noun phrase structure? University of Venice Working Papers in Linguistics 6 (2):105-128

\section{http://dspace-unive.cilea.it/bitstream/10278/471/1/6.2.4.pdf}

Godard, Danièle. 1992. Extraction out of NP in French. Natural Language and Linguistic Theory 10:233-277

Groos, Anneke and Henk van Riemsdijk. 1981. Matching Effects in Free Relatives: A Parameter of Core Grammar. In A.Belletti, L.Brandi and L.Rizzi, eds., Theory of Markedness in Generative Grammar. Proceedings of the 1979 GLOW Conference. 171-216. Pisa: Scuola Normale Superiore.

Gutiérrez-Bravo, Rodrigo. 2001. Phases, Case and Accessibility: the case of extraction from DP in Spanish. In J.McCloskey, ed., Syntax and Semantics at Santa Cruz 3. 104-118. Linguistics Research Center. University of California, Santa Cruz.

Haegeman, Liliane. 2004. DP-Periphery and Clausal Periphery: Possessor Doubling in West Flemish. In D.Adger, C. de Cat, and G.Tsoulas, eds., Peripheries. Syntactic Edges and their Effects. 211-240. Dordrecht: Kluwer.

Horrocks, Geoffrey and Melita Stavrou. 1987. Bounding theory and Greek syntax: evidence for wh-movement in NP. Journal of Linguistics 23:79-108 
Kayne, Richard S. 1980. Extensions of Binding and Case Marking. Linguistic Inquiry 11.7596

Kayne, Richard S. 1999. Prepositional complementizers as attractors. Probus 11: 39-73 (also in R. S. Kayne, Parameters and Universals. 282-313. New York: Oxford University Press). Kayne, Richard S. 2000. A note on prepositions, complementizers, and word order universals. In R. S. Kayne, Parameters and Universals, 314-326. New York: Oxford University Press. Kayne, Richard S. 2002. On some prepositions that look DP-internal: English of and French de. Catalan Journal of Linguistics 1: 71-115 (also in R.S.Kayne. Movement and Silence. 136175. New York: Oxford University Press, 2005)

Kayne, Richard S. 2004. Prepositions as probes. In A. Belletti, ed., Structure and Beyond: The Cartography of Syntactic Structures, vol. 3. 192-212. Oxford: Oxford University Press (also in R.S.Kayne. Movement and Silence. 85-104. New York: Oxford University Press, 2005) Kayne, Richard S. 2005. Some notes on comparative syntax, with special reference to English and French. In G. Cinque and R. S. Kayne, eds., The Oxford Handbook of Comparative Syntax, 3-69. New York: Oxford University Press. (also in R.S.Kayne. Movement and Silence. 277-333. New York: Oxford University Press, 2005)

Kayne, Richard S. 2008. Antisymmetry and the Lexicon. Linguistic Variation Yearbook 8:131 (also in R.S.Kayne Comparisons and Contrasts. 165-189. New York: Oxford University Press, 2010).

Kayne, Richard S. To appear. Why Isn’t This a Complementizer. In P.Svenonius, ed., Functional Structure from Top to Toe. New York: Oxford University Press (also in R.S.Kayne Comparisons and Contrasts. 190-227. New York: Oxford University Press, 2010). Kolliakou, Dimitra. 1999. De-phrase Extractability and Individual/Property Denotation. Natural Language and Linguistic Theory 17:713-781 
Krapova, Iliyana. 2002. On the Left Periphery of the Bulgarian sentence. University of Venice Working Papers in Linguistics 12:107-128

http://lear.unive.it/bitstream/10278/175/1/2002-4s-Krapova.pdf

Krapova, Iliyana and Guglielmo Cinque. 2008. On the Order of wh-Phrases in Bulgarian Multiple wh-Fronting. In G.Zybatow, L.Szucsich, U.Junghanns, R.Meyer, eds., Formal Description of Slavic Languages. 318-336. Frankfurt am Main: Peter Lang.

Kupferman, Lucien. 1996. Les génitifs: gouvernement d'antécédent et gouvernement thématique. Langue française 109:104-125

http://www.persee.fr/web/revues/home/prescript/article/lfr_0023-

8368_1996_num_109_1_5336

Longobardi, Giuseppe. 1991. Extraction from NP and the proper notion of head government. In A.Giorgi and G.Longobardi The Syntax of Noun Phrases. Configuration, parameters and empty categories. 57-112. Cambridge: Cambridge University Press.

Martín, Juan. 1993. On Extraction from NPs in Spanish. In W.J.Ashby, M.Mithun, G.Perissinotto, and E.Raposo, eds., Linguistic Perspectives on the Romance Languages. 303313. Amsterdam: Benjamins.

Milner, Jean-Claude. 1977. A propos des genitifs adnominaux en français. In C.Rohrer, ed., Actes du Colloque franco-allemand de linguistique théorique. 67-107. Tübingen: Niemeyer.

Milner, Jean-Claude. 1982. Ordres et Raisons de Langue. Paris: Seuil.

Mouma, Evangelia. 1993. On some properties of DPs in Modern Greek. UCL Working Papers in Linguistics 5: 75-101

http://www.ucl.ac.uk/psychlangsci/research/linguistics/publications/wpl/93papers/UCLWPL5 5_Mouma 
Mouma, Evangelia. 1994. Some Remarks on DPs in Modern Greek. In I.PhilippakiWarburton, K.Nikolaidis and M.Sifianou, eds., Themes in Greek Linguistics. 115-122. Amsterdam: Benjamins.

Moritz, Luc and Daniel Valois. 1994. Pied Piping and Specifier-Head Agreement. Linguistic Inquiry 25:667-707

Ntelitheos, Dimitrios. 2002. Possessor Extraction in Greek and the left periphery of the DP. Unpublished ms., UCLA. http://faculty.uaeu.ac.ae/dimitrios_n/Poss.pdf

Pollock, Jean-Yves. 1989. Opacity, Genitive Subjects, and Extraction from NP in English and French. Probus 1:151-162

Rizzi, Luigi. 1990. Relativized Minimality. Cambridge, MA: MIT Press.

Rizzi, Luigi. 2001. Relativized Minimality effects. In M.Baltin and C.Collins, eds., The Handbook of Contemporary Syntactic Theory. 89-110. Oxford: Oxford University Press.

Rizzi, Luigi. 2004. Locality and Left Periphery. In A.Belletti, ed., Structures and Beyond. The Cartography of Syntactic Structures, volume 3. 223-251. New York: Oxford University Press. Rizzi, Luigi. 2007. On Some Properties of Criterial Freezing. Studies in Linguistics (CISCL Working Papers) 1:145-158 http://www.ciscl.unisi.it/doc/doc_pub/STiL-2007-vol1.pdf Rizzi, Luigi and Ur Shlonsky. 2007. Strategies of Subject Extraction. In U.Sauerland and H.M. Gärtner, eds., Interfaces + Recursion = Language $?$ Chomsky's Minimalism and the View from Syntax-Semantics. 115-160. Berlin: Mouton de Gruyter.

http://www.ciscl.unisi.it/doc/doc_pub/rizzi_shlonsky2005.pdf

Ross, John Robert. 1967. Constraints on Variable in Syntax. Ph.D. Dissertation, MIT.

Ruwet, Nicolas. 1972. Comment traiter les irrégularités syntaxiques. - Contraintes sur les transformations ou stratégies perceptives? In N.Ruwet Théorie syntaxique et syntaxe du français. 252-286. Paris: Éditions du Seuil.

Shlonsky, Ur. 1988. Government and Binding in Hebrew Nominals. Linguistics 26: 951-976 
Sportiche, Dominique. 1989. Le mouvement syntaxique: contraintes et parameters. Langages 95: 35-80 (La géométrie du langage. Etat présent de la grammaire générative).

http://www.persee.fr/web/revues/home/prescript/article/lgge_0458-

726x_1989_num_24_95_1551

Steriade, Donca. 1981. Extraction from NP in Romance and Possessor Raising. Ms., MIT.

http://lear.unive.it/bitstream/10278/1753/1/Steriade.pdf

Stowell, Timothy. 1987. Subjects, Specifiers, and X-bar Theory. In M.Baltin and A.Kroch, eds., Alternative Conceptions of Phrase Structure. 232-262. Chicago: University of Chicago Press.

Szabolcsi, Anna. 1994. The Noun Phrase. In F.Kiefer and K.É.Kiss, eds., The Syntactic Structure of Hungarian. (Syntax and Semantics, vol. 27). 179-274. San Diego, CA: Academic Press.

Taraldsen, Knut Tarald. 1981. Case-conflict in Norwegian Topicalization. In V. Burke and J.

Pustejovsky, eds., Proceedings of the Eleventh Annual Meeting of the North Eastern

Linguistic Society. 377-398. Amherst, MA: GLSA (University of Massachusetts).

Ticio, Emma. 2010. Locality Domains in the Spanish Determiner Phrase. Dordrecht: Springer.

Torrego, Esther. 1986. On Empty categories in Nominals. Ms., MIT.

Torrego, Esther. 1988. Evidence for Determiner Phrases. Ms., University of Massachusetts, Boston

Valois, Daniel. 1991. The Internal Syntax of DP. Ph.D. dissertation, UCLA.

Zubizarreta, Maria Luisa. 1979. Extraction from NP and reformulation of subjacency. Ms. MIT. 